\title{
Review on Synthesis of Bioactive Pyrazoline Derivatives
}

\author{
S.SHARMA $^{1 *}$, SANDEEP KAUR ${ }^{2}$, TANIA BANSAL ${ }^{3}$ and JYOTI GABA ${ }^{3}$ \\ ${ }^{1}$ Department of Plant Breeding \& Genetics, Punjab Agricultural University, \\ Ludhiana-141004, India \\ ${ }^{2}$ Department of Soil Science, Punjab Agricultural University, Ludhiana-141004, India \\ ${ }^{3}$ Department of Chemistry, Punjab Agricultural University, Ludhiana-141004, India \\ sunita_sharm@pau.edu
}

Received 12 December 2013 / Accepted 2 January 2014

\begin{abstract}
Pyrazolines are prominent nitrogen-containing heterocyclic compounds and therefore, various procedures have been worked out for their synthesis. Pyrazolines have variety of methods for their synthesis but one of the popular methods is of Fischer and Knoevenagel i.e. the reaction of $\alpha, \beta$-unsaturated ketones with phenyl hydrazine in acetic acid under refluxing condition. However depending on the reactivity of molecules and need of the chemist, they had synthesized the pyrazolines under different solvent media and acidic or basic conditions.
\end{abstract}

Keywords: Pyrazolines, Claisen-Schmidt condensation, Chalcones, Biological activity

\section{Introduction}

Many heterocyclic compounds due to their specific activity are employed in the treatment of many infectious diseases. Their use in the treatment is attributed to their inherent toxicity to various pathogens. Among a wide range of heterocyclic compounds that have been explored for the development of pharmaceutically important molecules, pyrazolines constitute an interesting class of heterocycles due to their synthetic versatility and effective biological activities such as anticancer ${ }^{1}$, antioxidant ${ }^{2}$, antibacterial ${ }^{3}$, antifungal ${ }^{4}$, antidepressant ${ }^{5-7}$, antiinflammatory ${ }^{8}$, anticonvulsant ${ }^{9}$, antitumor ${ }^{10}$, analgesic ${ }^{11}$ properties.

Literature survey reveals several synthetic protocols for the synthesis of these compounds and the presence of this core in any molecule plays a key role in enhancing the activity. Phenyl ring containing halogen and methoxy groups have shown significant biological activities or enhance the biological activities of heterocyclic derivatives drastically ${ }^{12-14}$. An especially popular procedure is based on the reaction of $\alpha, \beta$-unsaturated aldehydes and ketones with hydrazines ${ }^{15-20}$. Such a glamour history prompted us to review the synthesis of pyrazolines as an urgent need which can possess biological and medicinal importance.

\section{Review}

Gupta $^{21}$ et al., (2010) reported a new, ultrasonic method for the synthesis of chalcones and pyrazolines. This is a two step process. In first step, 1, 3-diarylprop-2-en-1-ones were 
synthesized by Claisen-Schmidt condensation of aryl methyl ketones and 4-chlorobenzaldehyde in the presence of sdium hydroxide under ultrasonic irradiation. In the second step, synthesis of 2-pyrazolines was carried out by glacial acetic acid under ultrasonic irradiation at $25-45{ }^{\circ} \mathrm{C}$ temperature within 25-150 minutes. It had been observed that in conventional method, the mixture of chalcone, phenylhydrazine and glacial acetic acid was refluxed at $30-40{ }^{\circ} \mathrm{C}$ for 3-4 hours to produce 2- pyrazolines in 70\% yield. However when this reaction was carried out under sonication, the reaction completed rapidly within 30 minutes and yield was $80 \%$. The synthesized compounds were screened for their antimicrobial activity against bacteria and fungi and they showed good activity.<smiles>[X]c1cccc(C(C)=O)c1</smiles><smiles>O=Cc1ccc(Cl)cc1</smiles>

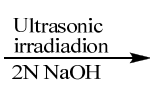<smiles>[X]c1ccc(C(=O)/C=C/c2ccc(Cl)cc2)cc1</smiles><smiles>[X]c1ccc(-c2cc(-c3ccccc3)n(-c3ccccc3)n2)cc1</smiles>

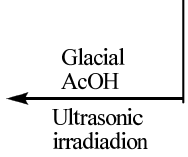

$$
\mathrm{X}=4-\mathrm{H}, 4-\mathrm{Br}, 4-\mathrm{Cl}, 4-\mathrm{F}, 4-\mathrm{CH}_{3}
$$

Scheme 1

Holla $^{22}$ et al.(2006) synthesized 3-aryl-5-(substituted phenyl/phenylfuranyl/thienyl)-2pyrazolines using Amberlyst-15 catalyst. 1-Aryl-3-(substituted phenyl/phenylfuranyl/ thienyl)2-propan-1-ones were synthesized by the condensation of a series of aromatic ketones with aromatic aldehydes under aldol conditions. The resulting propanones were subjected to a facile and clean cyclization reaction with hydrazine and substituted hydrazine derivatives to yield 3aryl-5--(substituted phenyl/phenylfuranyl/thienyl)-2-pyrazolines. This reaction was carried out in the presence of Amberlyst-15 catalyst to afford the pyrazolines in considerably good yield. All the synthesized compounds were characterized by spectral studies.

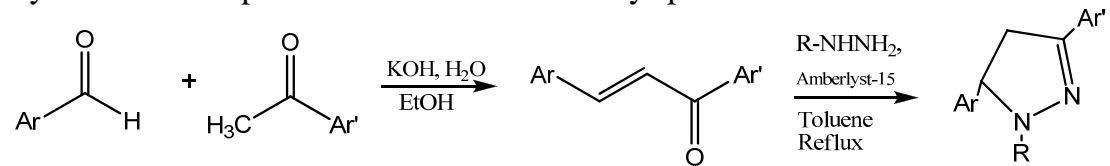

\section{Scheme 2}

Jayashankara and $\mathrm{Rai}^{23}$ (2008) synthesized a new series of pyrazoline bearing bisheterocycles via 1, 3-dipolar cycloaddition reactions. 2-Butyl-5-chloro-3H-imidazole-4carbaldehyde was alkylated using 4-bromomethyl-biphenyl-2-carbonitrile and potassium carbonate in DMF. The product was further reacted with phenyl hydrazine in the presence of sodium acetate to give corresponding phenyl hydrazone. Then oxidative dehydrogenation of phenyl hydrazone derivative by chloramines-T (CAT) afforded nitrile imine which was trapped by different olefins under refluxing condition in ethanol and the final product 4,5dihydro-3-(substituted imidazole)-5-substituted-1-phenyl-1 $H$-pyrazoline was obtained in good quality and yield which was identified by NMR spectroscopy and elemental analysis. These final compounds were screened for antimicrobial activity and showed potent to weak activity. The compounds with chloro and bromo groups showed better inhibition. 


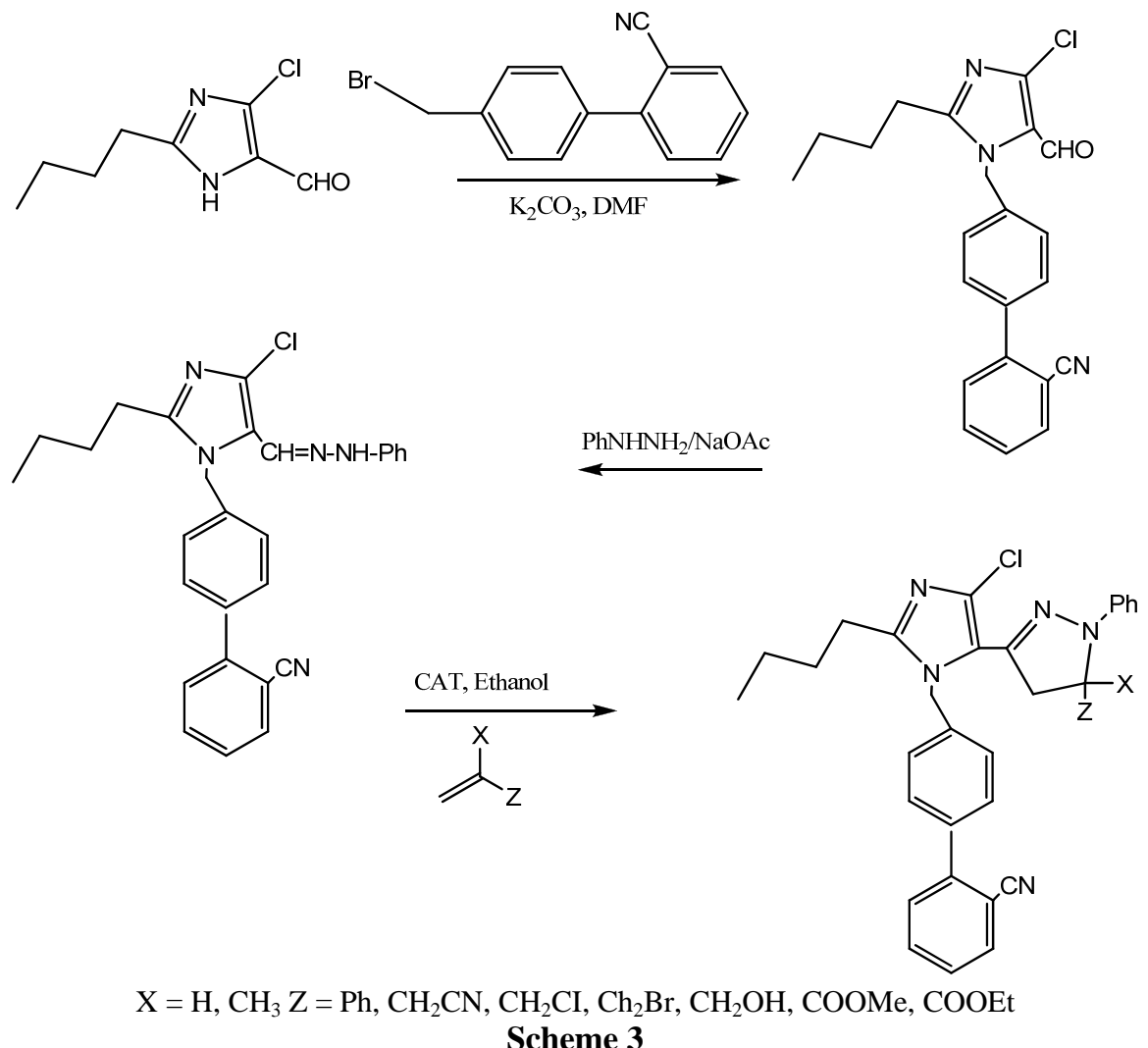

A series of 1, 3, 5-trisubstituted-2-pyrazoline derivatives were synthesized by Maleki ${ }^{24}$ et al., (2009) through cyclization of phenylhydrazine with $\alpha, \beta$-unsaturated ketones using methanoic acid as catalyst under thermal conditions. The effect of different solvents and amount of catalyst on the yield and time of the same reaction was investigated. It was found that ethanol was the best solvent and $2.5 \mathrm{~mL}$ of catalyst was sufficient to mediate the reaction towards the formation of 1, 3, 5- trisubstituted-2-pyrazoline derivatives in terms of time and yield.

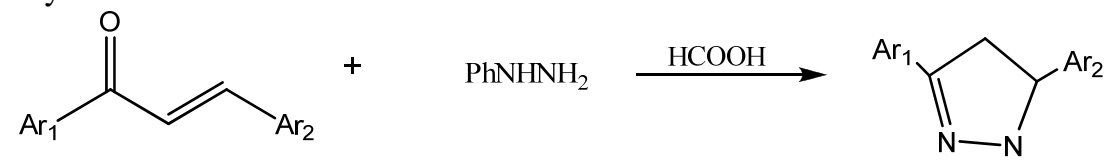

\section{Scheme 4}

Levai $^{25}$ et al., (2007) reported a method for the synthesis of tricyclic fused pyrazolines from chromanones and hydrazine hydrate. For the reaction, 3-arylidenechromanones and 3-arylidene-1-thiochromanones were allowed to react with hydrazine hydrate in hot acetic acid or in hot propionic acid and diastereomeric mixture of tricyclic fused pyrazolines were obtained in good yields. The diastereomeric mixture was separated by silica gel column chromatography using toluene:ethylacetate $(4: 1)$ as solvent. The structure and stereochemistry of isolated isomers were determined by spectroscopic methods. 

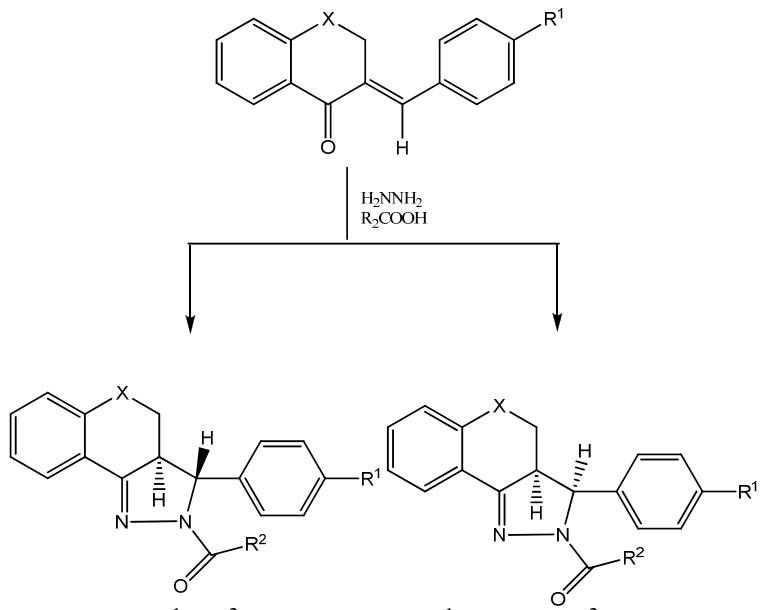

$\mathrm{X}=\mathrm{O}, \mathrm{R}^{1}=\mathrm{H}, \mathrm{R}^{2}=\mathrm{Me}, \mathrm{X}=\mathrm{O}, \mathrm{R}^{1}=\mathrm{R}^{2}=\mathrm{Me}, \mathrm{X}=\mathrm{O}, \mathrm{R}^{1}=\mathrm{MeO}, \mathrm{R}^{2}=\mathrm{Me}, \mathrm{X}=\mathrm{O}, \mathrm{R}^{1}=\mathrm{Cl}, \mathrm{R}^{2}=\mathrm{Me}$, $\mathrm{X}=\mathrm{O}, \mathrm{R}^{1}=\mathrm{H}, \mathrm{R}^{2}=\mathrm{Et}, \mathrm{X}=\mathrm{O}, \mathrm{R}^{1}=\mathrm{Me}, \mathrm{R}^{2}=\mathrm{Et}, \mathrm{X}=\mathrm{O}, \mathrm{R}^{1}=\mathrm{MeO}, \mathrm{R}^{2}=\mathrm{Me}, \mathrm{X}=\mathrm{O}, \mathrm{R}^{1}=\mathrm{Cl}, \mathrm{R}^{2}=\mathrm{Et}$, $\mathrm{X}=\mathrm{S}, \mathrm{R}^{1}=\mathrm{H}, \mathrm{R}^{2}=\mathrm{Me}, \mathrm{X}=\mathrm{S}, \mathrm{R}^{1}=\mathrm{R}^{2}=\mathrm{Me}, \mathrm{X}=\mathrm{S}, \mathrm{R}^{1}=\mathrm{MeO}, \mathrm{R}^{2}=\mathrm{Me}, \mathrm{X}=\mathrm{S}, \mathrm{R}^{1}=\mathrm{H}, \mathrm{R}^{2}=\mathrm{Et}, \mathrm{X}=\mathrm{S}, \mathrm{R}^{1}$ $=\mathrm{Me}, \mathrm{R}^{2}=\mathrm{Et}, \mathrm{X}=\mathrm{S}, \mathrm{R}^{1}=\mathrm{MeO}, \mathrm{R}^{2}=\mathrm{Et}$

\section{Scheme 5}

Four pyrazole compounds namely 3-(4-flourophenyl)-5-phenyl-4,5-dihydro- $1 \mathrm{H}$ pyrazole-carbaldehyde, 5-(4-bromophenyl)-3-(4- flourophenyl) -4,5-dihydro-1 $H$-pyrazolecarbaldehyde, 1-[5-(4-chlorophenyl)-3-(4-flourophenyl) -4,5-dihydro-1 $H$-pyrazol-1-yl] ethanone and 1-[3-(4-flourophenyl)-5-phenyl-4,5-dihydro-1 $H$-pyrazol-1-yl]propan-1-one have been prepared by $\mathrm{Loh}^{26}$ et al., (2013) by condensing chalcones with hydrazine hydrate in the presence of aliphatic acids namely formic acid, acetic acid and propionic acid. The structures were characterized by x-ray single crystal structure determination.<smiles>NCCNN</smiles>

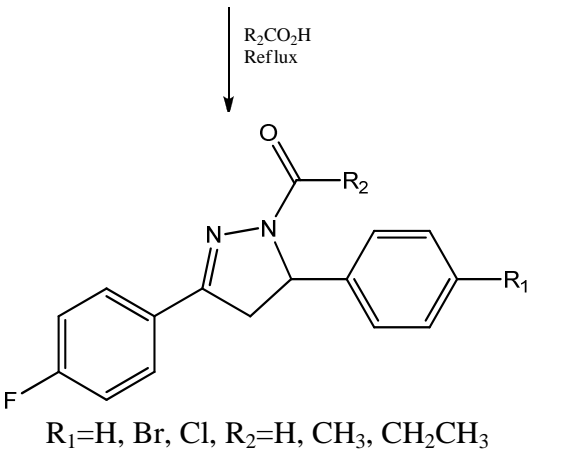

\section{Scheme 6}

Synthesis of some new substituted 1, 3, 5-triaryl pyrazolines was reported by Shandala ${ }^{27}$ et al (2008). Substituted chalcones were synthesized by the Claisen-Schmidt condensation of substituted benzaldehydes and acetophenones. Then these chalcones were reacted with 
phenyl hydrazine under phase transfer catalysis (PTC) conditions employing tetrabutyl ammonium iodide (TBAI) as a catalyst to synthesize 1, 3, 5-triarylpyrazolines. The structures of all products were elucidated by physical and spectroscopic methods.

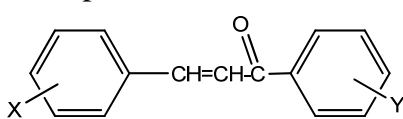

$\mathrm{X}=\mathrm{H}, 2-\mathrm{Cl}, 4-\mathrm{Cl}, 2,4-\mathrm{diCl}, 3,4-\mathrm{diCl}$, $\mathrm{Y}=\mathrm{H}, 4-\mathrm{Cl}, 4-\mathrm{Me}, 2-\mathrm{OMe}$

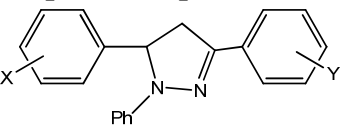

$\mathrm{X}=\mathrm{H}, 2-\mathrm{Cl}, 4-\mathrm{Cl}, 2,4-\mathrm{Cl}, 3,4-\mathrm{Cl}, \mathrm{Y}=\mathrm{H}$, 4-Cl, 4-Me, 2-OMe

\section{Scheme 7}

Some new 2- pyrazolines were synthesized by Mokle $^{28}$ et al., (2010) using triethanolamine as reaction solvent. The starting material, chalcones were produced by conventional ClaisenSchmidt condensation of 2-chloro-6-methyl-quinoline-3-carbaldehyde and substituted acetophenones. These chalcones were reacted with hydrazine hydrate/ phenyl hydrazine hydrate in the presence of triethanolamine within 15-20 minutes. The structures of synthesized compounds were determined by spectroscopic data and elemental analysis. These compounds were screened for antibacterial activity and they showed better activity against all tested bacteria.<smiles>[R]c1c(C(=O)/C=C/c2cc3cc(C)ccc3nc2Cl)cc([2H])c(Br)c1Br</smiles>

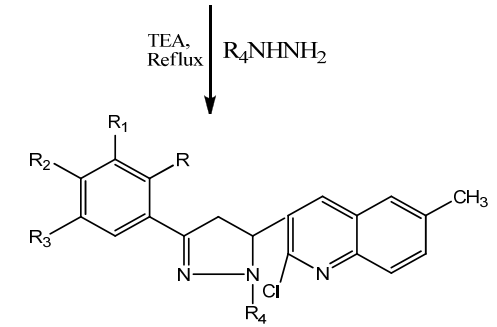

$$
\mathrm{R}=\mathrm{OH}, \mathrm{H} \mathrm{R}_{1}=\mathrm{I}, \mathrm{R}_{2}=\mathrm{H}, \mathrm{OH} \mathrm{R} \mathrm{R}_{2}=1, \mathrm{Cl} \mathrm{R}_{4}=\mathrm{H}
$$

Scheme 8

Sridhar and Rajendraprasad ${ }^{11}$ (2012) synthesized some new 2-pyrazolines and studied their analgesic activity. Pyrazolines were synthesized in a two step process. In first step, 3acetyl-2,5-dimethylfuran and appropriate aldehydes were reacted in the presence of ethanol and aqueous $\mathrm{KOH}$ to afford 1-(2`,5`-dimethyl-3`-foryl)-3-(aryl)-2-propen-1-one. Then these compounds were condensed with phenyl hydrazine in the presence of pyridine in refluxing ethanol to prepare 1-phenyl-3-(2`,5`-dimethyl-3`-foryl)-3-(aryl)-2-pyrazoline.

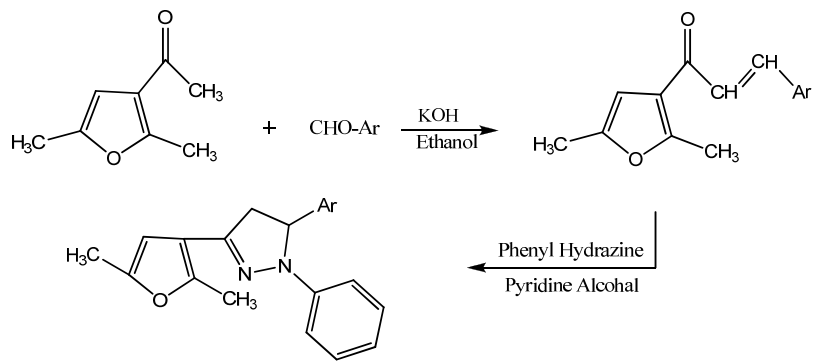

Scheme 9 
Claisen-Schmidt condensation was used for the synthesis of chalcone intermediates from various halogen substituted benzaldehydes and 20 acetyl indole in ethanol in the presence of $10 \% \mathrm{NaOH}$ solution. All the chalcones were treated with hydrazine hydrate in hot glacial acetic acid to afford 1-acetyl-3,5-diaryl-2-pyrazolines in good yield. These synthesized acetylated pyrazoline derivatives were screened for their anti-inflammatory activity by membrane stabilization method. These compounds showed effective stabilization of RBC membrane. This work was reported by Suman ${ }^{29}$ et al., (2011).<smiles>CC(=O)c1c[nH]c2ccccc12</smiles><smiles>[R]c1ccc(C=O)cc1</smiles><smiles>[R]c1ccc(/C=C/C(=O)c2c[nH]c3cc([N+]([O-])([O-])O)ccc23)cc1</smiles><smiles>[R]c1ccccc1-c1cc(-c2c[nH]c3ccccc23)nn1C(C)=O</smiles>

$\mathrm{R}=\mathrm{H}, \mathrm{F}, \mathrm{Cl}$

Scheme 10

1-(2-Carboxyphenyl)-2-pyrazolines and 1-(4-Carboxyphenyl)-2-pyrazolines had been synthesized by Levai and $\mathrm{Jeko}^{30}$ (2009) by the treatment of appropriate 3-aryl-1-(3coumarinyl) propen-1-ones with (2-carboxyphenyl) hydrazine and (4-carboxyphenyl) hydrazine in hot acetic acid. The structures of all new synthesized 2-pyrazolines had been elucidated by microanalysis and spectroscopic measurements.

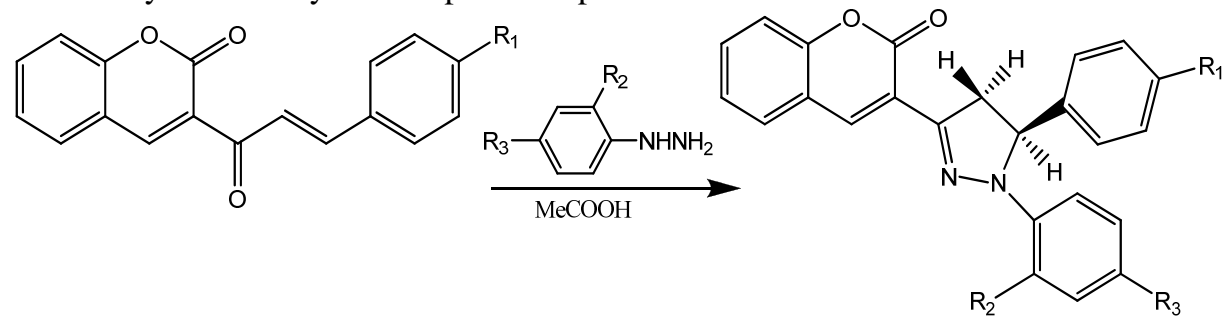

$\mathrm{R}_{1}=\mathrm{H}, \mathrm{Me}, \mathrm{iPr}, \mathrm{MeO}, \mathrm{F}, \mathrm{Cl}, \mathrm{Br}^{-}, \mathrm{R}_{2}=\mathrm{R}_{3}=\mathrm{H}, \mathrm{COOH}$

\section{Scheme 11}

Hawaiz $^{31}$ et al., (2011) reported a method for the synthesis of some new chalcones and then their transformation of pyrazoline derivatives. A series of new chalcone derivatives containing benzyloxy moiety have been synthesized on the basis of base catalyzed ClaisenSchmidt condensation in high yields from the reaction of prepared starting material 3-(4-chlorobenzyloxy)paraldehyde with different substituted acetophenones. The prepared chalcones were treated with hydrazine hydrate according to the Michael addition reaction to obtain new pyrazoline derivatives. 


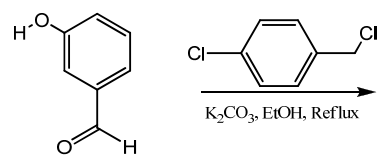<smiles>O=Cc1cccc(OCc2ccc(Cl)cc2)c1</smiles>

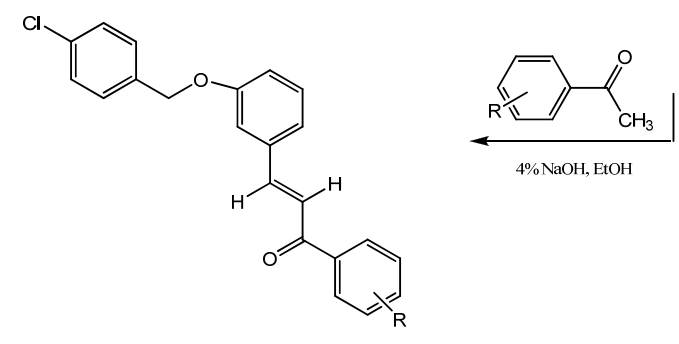

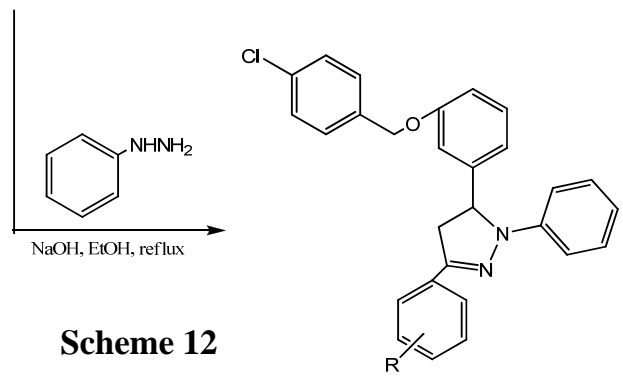

$\mathrm{R}=4-\mathrm{Br}$, 4-F, 4-Cl, 4-Me, 4-OMe, 4-H, 2-Naph, 4-Ph, 4- $\mathrm{OCH}_{2} \mathrm{Ph}$

Based on the biological activities exhibited by the pyrazoline compounds, Revanasiddappa ${ }^{32}$ et al., (2010) reported the synthesis and biological evaluation of some novel pyrazoline derivatives. First, the chalcones were prepared fron substituted aldehydes and ketones in the presence of alkali $\mathrm{NaOH}$ and alcohol as solvent medium. Then the chalcones were converted into 1,3,5-trisubstituted pyrazoline derivatives by reacting with isoniazid (INH) in glacial acetic acid medium. The structures of newly synthesized compounds were established by spectroscopy. All the synthesized compounds were evaluated for their antibacterial and antifungal activities and it was found that most of the compounds were moderately active against both bacteria and fungi.

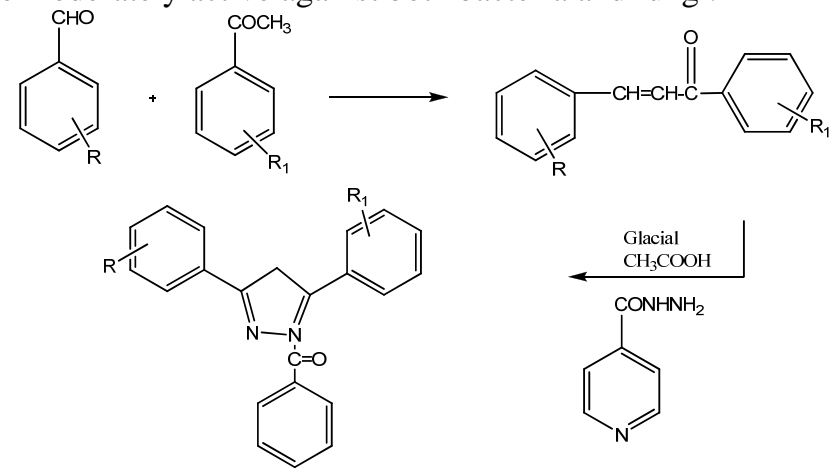

$\mathrm{R}=$ 2-furfural, p- $\mathrm{CH}_{3}, \mathrm{p}-\mathrm{Cl}, \mathrm{C}_{6} \mathrm{H}_{5}, \mathrm{p}-\mathrm{OCH}_{3}$, 2-Thiophene, m-NO2, p- $\left(\mathrm{CH}_{3}\right)_{2}-\mathrm{N}, \mathrm{p}-\mathrm{OCH}_{3}, \mathrm{p}-\mathrm{Cl}, \mathrm{p}-\mathrm{OH}$, $\mathrm{p}-\mathrm{NO}_{2}, \mathrm{C}_{6} \mathrm{H}_{5}, \mathrm{p}-\mathrm{Br}$

\section{Scheme 13}


A series of novel pyrazolines were synthesized by refluxing piperazine chalcones and hydrazine hydrate in the presence of alkali. This was reported by Shah ${ }^{33}$ et al., . The synthesized pyrazolines were subjected to antimicrobial studies and exhibited moderate to good activity.

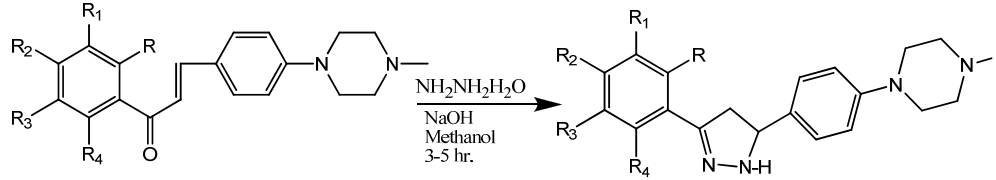

$\mathrm{R}=\mathrm{H}, \mathrm{OCH}_{3}$, OH; $\mathrm{R}_{1}=\mathrm{H}, \mathrm{F}, \mathrm{Br}, \mathrm{Cl}, \mathrm{I} ; \mathrm{R}_{2}=\mathrm{H}, \mathrm{Br}, \mathrm{OCH}_{3}, \mathrm{OH}, \mathrm{CH}_{3} ; \mathrm{R}_{3}=\mathrm{H}, \mathrm{OCH}_{3}, \mathrm{Cl}_{1} \mathrm{CH}_{3} ; \mathrm{R}_{4}=\mathrm{H}$

\section{Scheme 14}

Hareesh $^{34}$ et al., (2012) synthesized some novel pyrazoline derivatives from commercially available 2-hydroxy-aceto-naphthanone and substituted vanillin derivative. First the key intermediate chalcone was prepared by treting 2-hydroxy-aceto-naphthanone with aldehyde in the presence of $\mathrm{NaOH}$ in methanol. chalcones were then treated with hydrazine hydrate in the presence of sodium acetate in ethanol to give a pyrazoline that was further alkylated to some new pyrazoline derivatives. These derivatives were then screened for their antibacterial activity. All the compounds exhibited good activity. The compounds having amide functionality exhibited excellent activity against bacteria.<smiles>CCCOc1ccc(/C=C/C(=O)c2c(O)ccc3ccccc23)cc1OC</smiles><smiles>CCCOc1ccc(C2CC(c3c(C)ccc4ccccc34)=NN2)cc1OCCC</smiles>

a $\mathrm{R}=-\mathrm{Me}, \mathrm{b} \mathrm{R}=-\mathrm{Et}$, c $\mathrm{R}=-\mathrm{Pr}, \mathrm{d} \mathrm{R}^{\prime}=-\mathrm{Ph}$, e $\mathrm{R}^{\prime}=-\mathrm{Ph}, 4 \mathrm{Cl}, \mathrm{f} \mathrm{R}^{\prime}=-\mathrm{Ph}, 4 \mathrm{CH}_{3}$, g R'= $-\mathrm{Ph}, 4-\mathrm{OMe}$, h R'= - $\mathrm{COCH}_{3}$, I R'= -COPh, k R'= -COPh, 4-Cl, l R'= -COPh, 4-OME

\section{Scheme 15}

Reagents and conditions: a) $\mathrm{NaOH}$, Methanol, rt, $12 \mathrm{~h}$ b) $\mathrm{NH}_{2} \mathrm{NH}_{2} \mathrm{H}_{2} \mathrm{O}$, NAOAc, ethanol, reflux, 6 h; c) R-Br,Et ${ }_{3} \mathrm{~N}$ DCM,rt, 24h; d) $-\mathrm{NH}_{2} \mathrm{NH}_{2}, \mathrm{NaOAc}$, ethanol, refulx, $10 \mathrm{~h}$

Joshi $^{35}$ et al., (2012) also synthesized some pyrazolines from chalcones. Chalcones were prepared by treatment of furan-2-carbaldehyde with different acetophenones by Claisen-Schmidt condensation. Then various pyrazoline derivatives were prepared by reflux reaction of chalcones 
with phenyl hydrazine/hydrazine hydrate in ethanolic solution. The structures of newly synthesized compounds were established on the basis of their spectral data. All synthesized pyrazoline derivatives were screened for their antimicrobial activity against some bacteria and fungi.
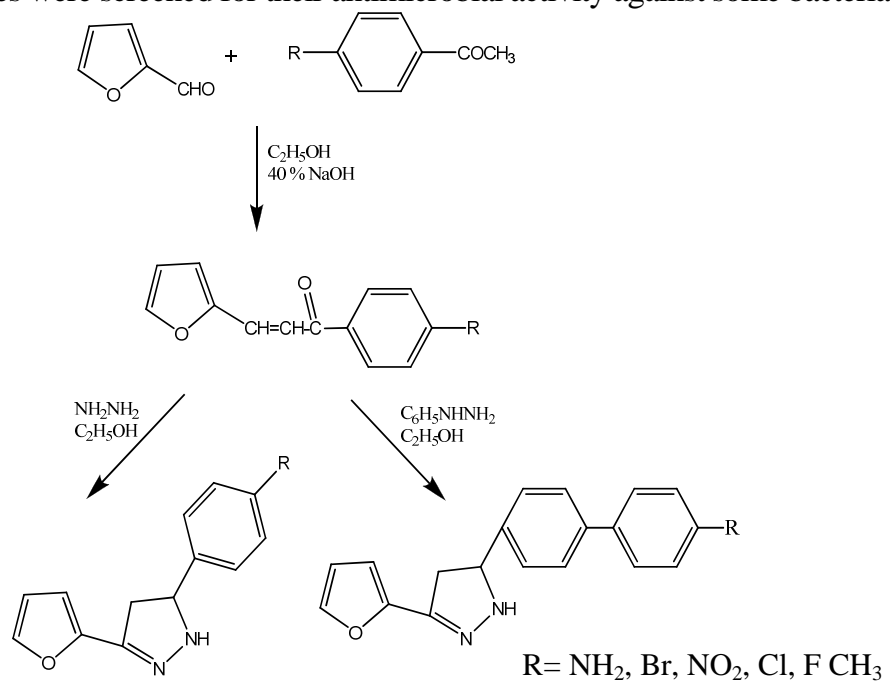

Scheme 16

Azarifar and Shaebanzadeh ${ }^{36}$ (2002) synthesized some new 3,5-dinaphthyl substituted 2-pyrazolines and studied their antimicrobial activity. 3, 5-Dinaphthalene-1-yl substituted 2-pyrazolines containing certain groups as substituents on both the naphthalene and pyrazoline rings were prepared by the action of hydrazine reagents on chalcones that were also prepared by aldol condensation reaction between the corresponding 1-acetylnaphthalenes and 1-naphthaldehydes in ethanolic $\mathrm{NaOH}$ solution. Formation of all the compounds was confirmed by spectroscopy (NMR and FTIR). All the compounds were tested in vitro for antimicrobial activity against the test organisms Escherichia coli, Staphylococcus aureus, Klebsiella pneumonia, Proteus mirabilis, Shigella dysentery and Salmonella typhii. It was observed that $80 \%$ of the total tested compounds showed some antimicrobial activity.

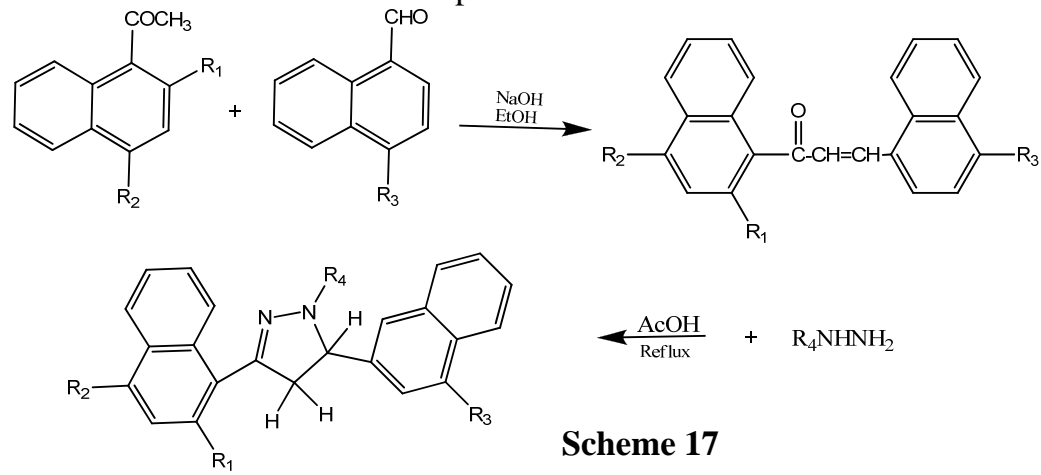

$\mathrm{R}_{1}=\mathrm{H}, \mathrm{OH} ; \mathrm{R}_{2}=\mathrm{H}, \mathrm{Cl}, \mathrm{Me} ; \mathrm{R}_{3}=\mathrm{H}, \mathrm{NMe}_{2} ; \mathrm{R}_{4}=\mathrm{H}, \mathrm{Ph}, \mathrm{CONH}_{2}, \mathrm{COCH}_{3}$

Ramesh and Sumana ${ }^{37}$ synthesized some new pyrazoline derivatives by reacting chalcones of 2-acetyl thiophene with phenyl hydrazine hydrochloride in the presence of alcohol. The synthesized compounds were tested for their anti-inflammatory activity and recorded moderate to considerable activity. 


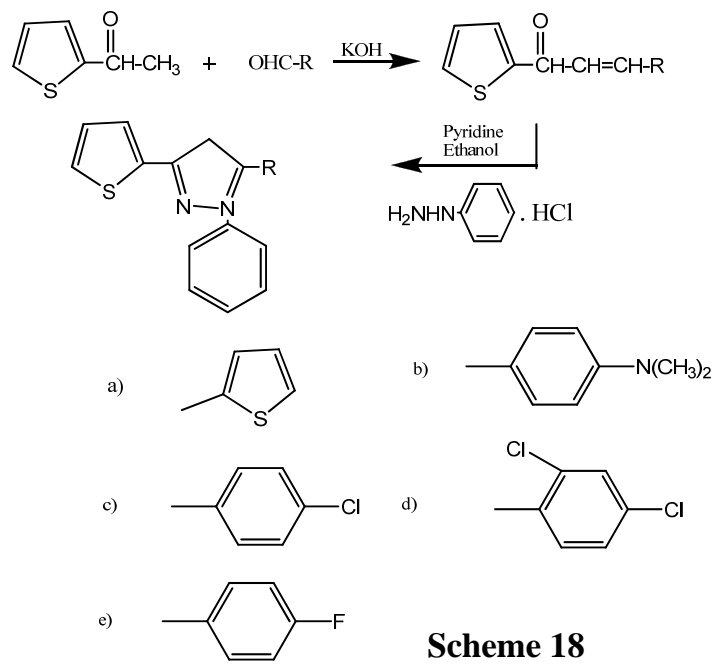

Jyothi $^{38}$ et al., (2012) also synthesized some novel pyrazolines with antimicrobial activity. This is a two step process. In first step, 3-acetylpyridine and respective aldehydes were reacted in alcohol in the presence of $40 \%$ aqueous $\mathrm{KOH}$ solution to afford chalcones. Then in second step, the chalcones were reacted with phenyl hydrazine hydrochloride in ethanol under refluxing conditions to get the final product namely 1-phenyl-3-(3`-pyridyl)-5-(substituted phenyl)-2-pyrazoline derivatives. These were then screened for their antibacterial and antifungal activity and it was observed that pyrazoline containing flouro substitution at para position on phenyl ring enhanced both antibacterial and antifungal activities.

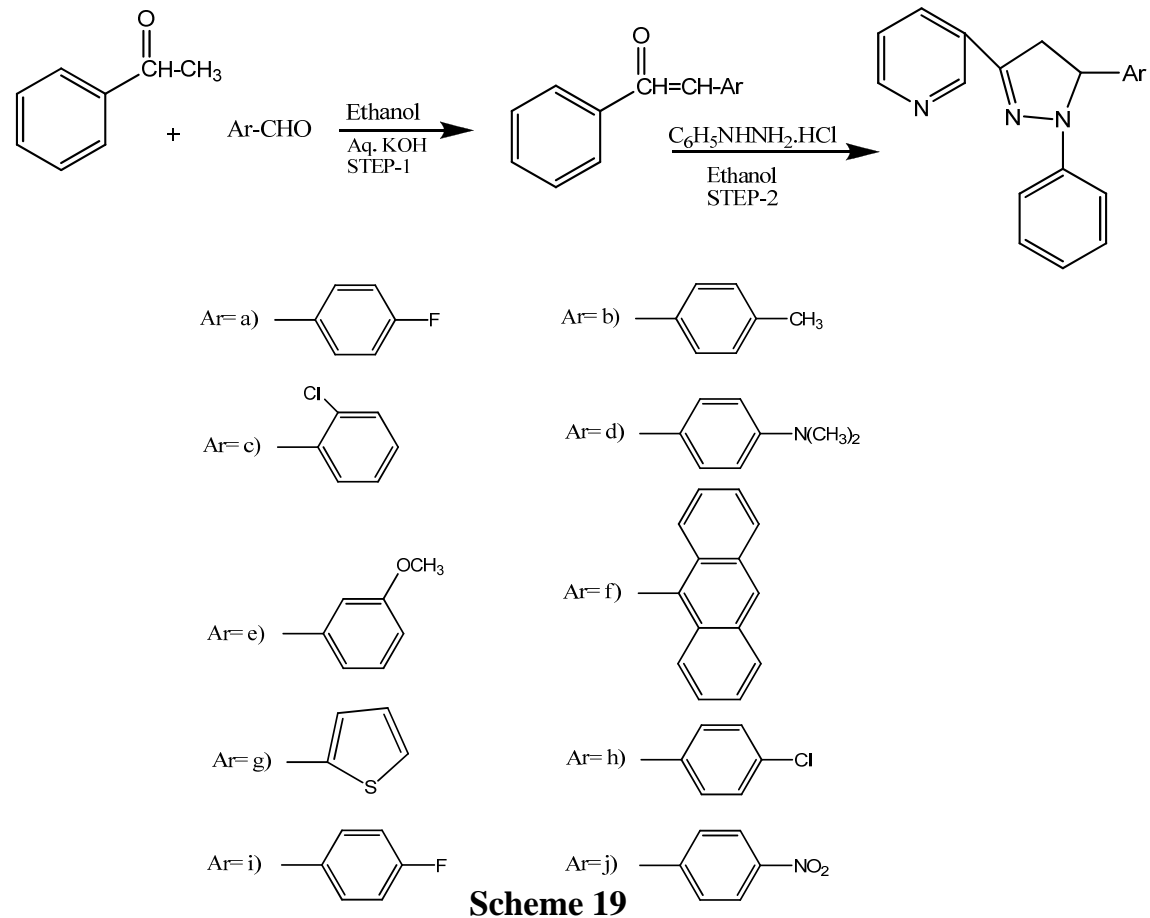


Some new 3, 5-diphenyl and 1, 3, 5-triphenyl-2-pyrazoline derivatives were synthesized by Shinde ${ }^{39}$ et al., (2004) and the antibacterial activities were studied by using three different pathogenic bacteria. 1,3-Diphenyl-2-propen-1-ones (chalcones)were synthesized by condensing appropriate acetophenones with benzaldehydes in dilute ethanolic sodium hydroxide solution at room temperature. The 3,5-diphenyl-2-pyrazolines and 1,3,5-triphenyl-2pyrazolines were synthesized by the reaction of appropriate 1,3-diphenyl propen-1-one derivatives with hydrazine hydrate and phenyl hydrazine according to the condensation reaction of $\alpha, \beta$-unsaturated ketones with hydrazines in yields varying from $83-95 \%$. Most of the new synthesized pyrazoline derivatives were tested for their antibacterial activity in vitro against bacterial strains such as E.coli, S. Typhi and S.dysentrae and the results showed that all the compounds exhibited a marked degree of activity against bacteria at MIC of $50 \mu \mathrm{g} / \mathrm{mL}$.<smiles>[R]c1cc(Br)ccc1C(C)=O</smiles><smiles>[R]c1cc(Br)ccc1C(=O)/C=C/c1cc([2H])c(O)c(OC)c1</smiles>

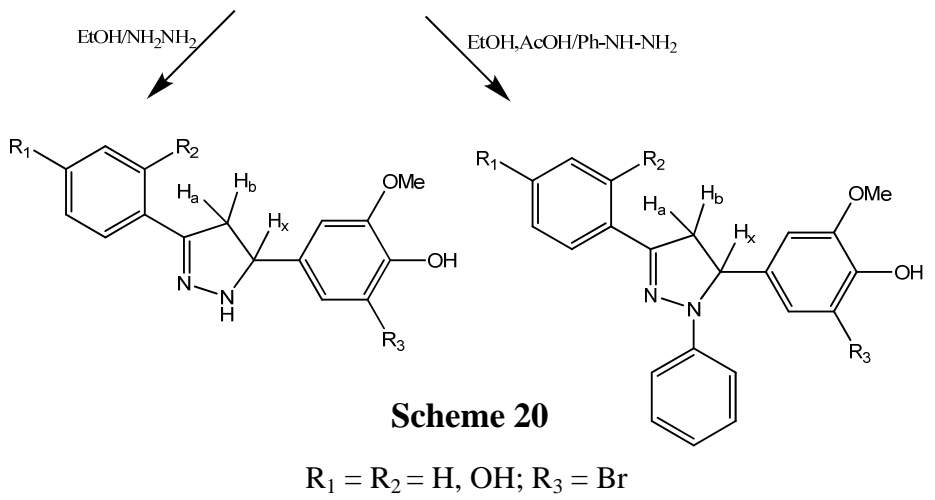

A series of new pyrazolines and isoxazoles had been synthesized by Karabasanagouda $^{40}$ et al., (2009). The key intermediates 1-[4-(methylthio) phenyl]-3aryt/heteroaryl-propen-1-ones were prepared by treating 4-acetylthioanisol with substituted aryl/heteroaryl aldehydes inthe presence of $\mathrm{NaOH}$ according to Claisen-Schmidt condensation. These propanones were used as precursors for the synthesis of pyrazolines and osoxazoles. These propanones on treatment with hydrazine hydrate in ethanol afforded 3-[4-(methylthio) phenyl]-5-aryt/heteroaryl-pyrazolines and on treatment with hydroxyl amine hydrochloride in dimethylformamide and sodium acetate yielded 3-[4-(methylthio) phenyl]-5-aryt/heteroaryl isoxzoles. All these synthesized compounds were characterized by spectroscopy and were screened for their analgesic and anti-inflammatory activities. The biological study revealed that a few compounds showed moderate to good activity. 


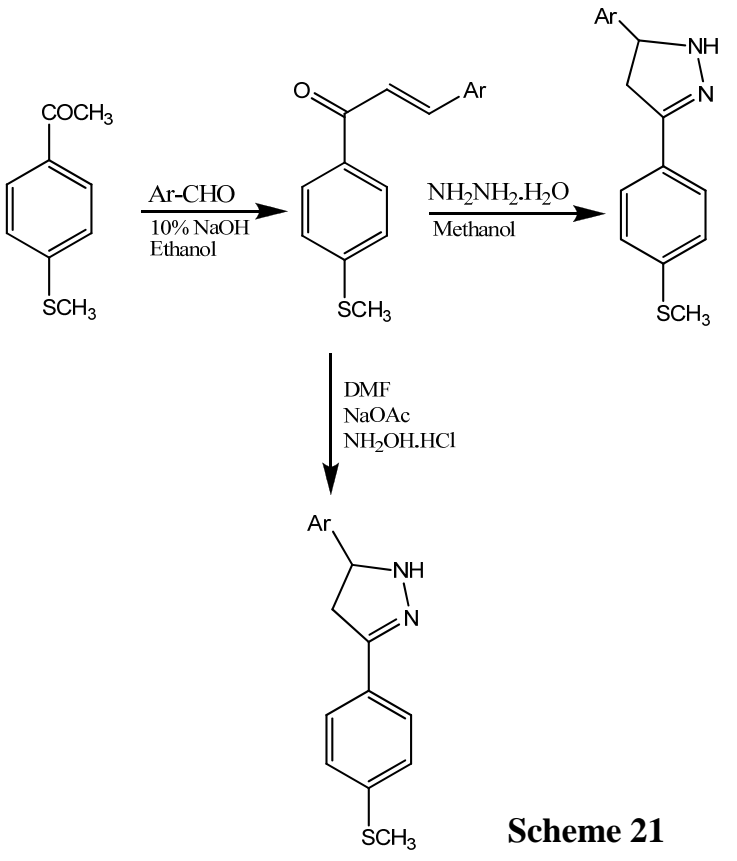

Ar=4-methylphenyl, phenyl,4-methoxyphenyl, 4-chlorophenyl, biphenyl, 3,4dimethoxyphenyl, 2-amino-3-pyridyl, 4-methoxy-2,3,6-trimethylphenyl, 2-bromo-6-nitriphenyl, 2,4,5-trichlorophenyl, 6-methoxy-2napthyl

Gothwal and Srivastava ${ }^{41}$ (2012) reported a novel and easy access to substituted 2-pyrazolines using a one-pot procedure and demonstrated its superiority over previously reported classical heating methods. First the substituted 4 -(4“-nitrophenoxy)chalcones were synthesized by irradiating a solution of 4-(4`-nitrophenoxy)acetophenone and substituted aryl aldehyde in methanol under microwave irradiation for 3-4 minutes at 300 Watt. Then the solution of these chalcones and hydrazine hydrate in hot formic acid was also irradiated under microwave oven at 600 watt for 2-4 minutes to afford 3-[4`-(4“-nitrophenoxy)-phenyl]-5(substituted aryl)-2-pyrazoline-1-carboxaldehydes. The progress of reaction was monitored by TLC and the product was recrystallized. All the synthesized compounds were screened for their antimicrobial activities and some of compounds showed potential antimicrobial activities.<smiles>[R]c1ccc(/C=C/C(=O)c2ccc(Oc3ccc([N+](=O)[O-])cc3)cc2)cc1</smiles> 


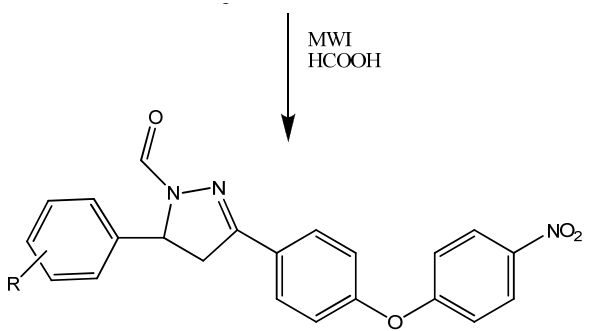

\section{Scheme 23}

$$
\mathrm{R}=\mathrm{H}, 4-\mathrm{N}\left(\mathrm{CH}_{3}\right)_{2}, 4-\mathrm{Cl}, 3,4\left(\mathrm{OCH}_{3}\right), 4-\mathrm{OCH}_{3}, 4,5(\mathrm{OCH})_{3}
$$

Adhikari $^{42}$ et al., (2012) proposed the synthesis, characterization and pharmacological study of 4,5-dihydropyrazolines carrying pyrimidine moiety. The reaction of 1,1,3,3tetramethoxy propane with urea in the presence of conc. $\mathrm{HCl}$ in methanol medium afforded 2-hydroxypyrimidine, which on further reaction with bromine yielded 5-bromo-2hydroxypyrimidine. It was then converted to 5-bromo-2-chlororimidine with $\mathrm{POCl}_{3}$ at 105 $110{ }^{0} \mathrm{C}$. 5-Bromo-2-chlororimidine by reacting with hydrazine resulted into 5-bromo-2pyrimidinylhydrazine which was then reacted with 1,3-diaryl-2-propen-1-one furnished 5-bromo-2-(3,5-dihydro-1 $H$-pyrazol-1-yl)pyrimidine using conventional heating and microwave irradiation techniques. These pyrazolines were screened for their antioxidant, anti-inflammatory and analgesic activities.
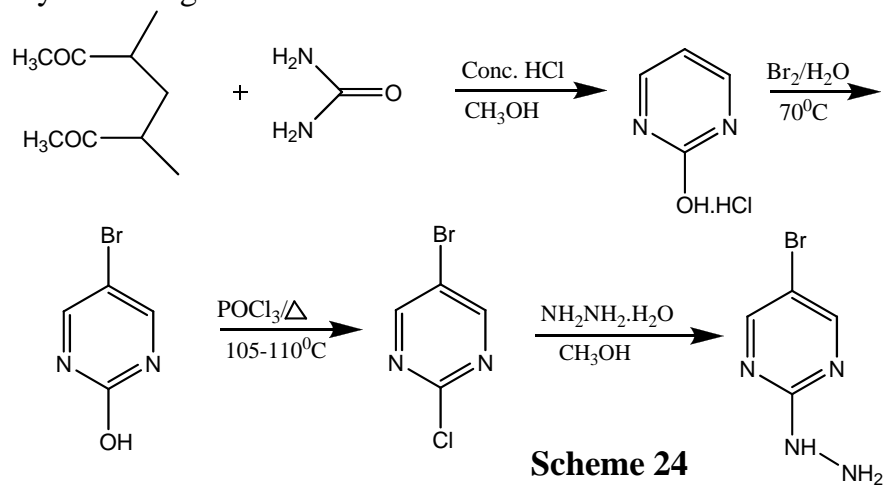

With the persuasion to synthesize the molecules of biological interest $\operatorname{Shah}^{43}$ et al., (2011) reported the synthesis of pyrazolines from pyrrolidine chalcones. Equimolar solution of pyrrolidine chalcones and phenyl hydrazine in methanol was refluxed for few hours in the presence of $\mathrm{NaOH}$ to afford corresponding pyrazolines. These were also screened for their antimicrobial activity using cup plate method and it was found that the synthesized compounds recorded moderate to good activity against both bacteria and fungi.

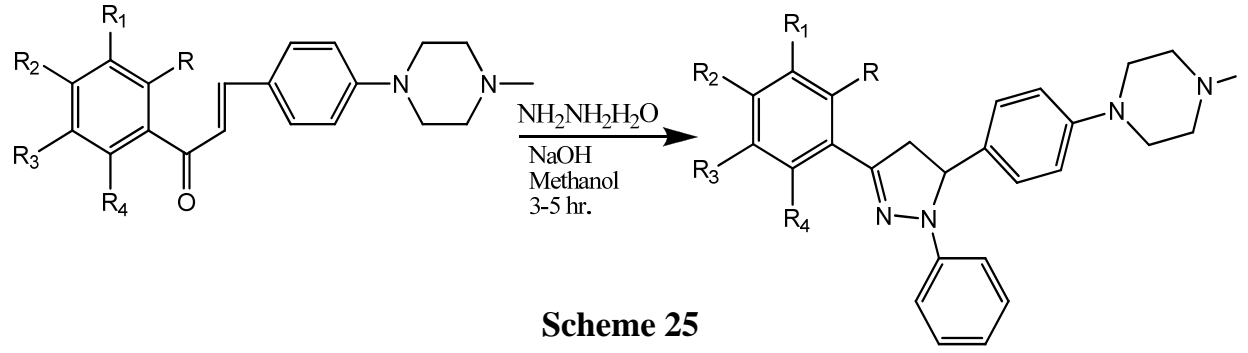

$\mathrm{R}=\mathrm{H}, \mathrm{OCH}_{3}, \mathrm{OH} ; \mathrm{R}_{1}=\mathrm{H}, \mathrm{Cl}, \mathrm{I} ; \mathrm{R}_{2}=\mathrm{H}, \mathrm{OCH}_{3}, \mathrm{OH}, \mathrm{CH}_{3} ; \mathrm{R}_{3}=\mathrm{H}, \mathrm{OCH}_{3}, \mathrm{Cl} ; \mathrm{R}_{4}=\mathrm{H}$ 


\section{Conclusion}

Pyrazolines are well known and important nitrogen containing 5-membered heterocyclic compounds and various methods have been worked out for their synthesis. Numerous pyrazoline derivatives have been found to possess considerable biological activities, which stimulated the research activity in this field. The manuscript is a brief review about different methods for the synthesis of biologically active pyrazoline derivatives.

\section{References}

1. $\quad$ Nimavat K S, Popat K H and Joshi H S, Indian J Hetrocycl Chem., 2003, 12, 225-228.

2. Venkatesh P, Hari Prasath K, Sharfudeen S, Soumya V, Spandana V and Priyanka J, $J$ Pharm Res., 2012, 5(5), 2875-2877.

3. Seham Y H, Molecules, 2013, 18(3), 2683-2711; DOI:10.3390/molecules18032683

4. $\quad$ Shailesh H S and Pankaj S P, Chem Sci Trans., 2012, 1(3), 632-637; DOI:10.7598/cst2012.274

5. $\quad$ Palaska E, Aytemir M, Uzbay T and Erol D, Eur J Med Chem., 2001, 36(6), 539-543; DOI:10.1016/S0223-5234(01)01243-0

6. Rajendra Prasad Y, Lakshmana Rao A, Prasoona L, Murali K and Ravi Kumar P, Bioorg Medl Chem Lett., 2005, 15(22), 5030-5034; DOI:10.1016/j.bmcl.2005.08.040

7. Palaska E, Erol D and Demirdamar R, Eur J Med Chem., 1996, 31(1), 43-47; DOI:10.1016/S0223-5234(96)80005-5

8. Ozdemir Z, Kandilici B H, Gumucel B, Calis U and Bilgin A A, Eur J Med Chem., 2007, 42(3), 373-379; DOI:10.1016/j.ejmech.2006.09.006

9. Ramesh B and Sumana T, J Chem., 2010, 7(2), 514-516; DOI:10.1155/2010/731675

10. Jainey P J and Bhat I K. J Young Pharm., 2012, 4(2), 82-87; DOI:10.4103/0975-1483.96621

11. Sridhar S and Rajendraprasad Y, J Chem., 2012, 9(4), 1810-1815; DOI:10.1155/2012/476989

12. Saify Z S and Faiyaz M. V, Pakistan J Pharm Sci., 1998, 3(1), 15-21.

13. Kuthiriya P J and Purohit D M, J Chem Pharm Res., 2012, 4(1), 383-386.

14. Manikandan D, Krishnaraj K and Nanjan M J, Int J Chem Res., 2012, 4, 532-538.

15. Bhatnagar I and George M V, Tetrahedron, 1968, 24(3), 1293-1298; DOI:10.1016/0040-4020(68)88080-9

16. Aubagnac J L, Elguero J and Jacquier R, Bull Soc Chim Fr., 1969, 3292.

17. Weber F G, Brosche K, Seedorf Ch and Rinow A, Monatsh fur Chem., 1969, 100(6), 1924-1927; DOI:10.1007/BF01151742

18. Joshi M G and Wadodkar K N, Indian J Chem., 1981, 20B, 1090.

19. Sharma T C, Pawar S R and Reddy N J, Acta Chim Hung., 1983, 112, 159.

20. Dhar D N and Raghunathan R, Indian J Chem., 1984, 23B, 1187.

21. Gupta R, Gupta N and Jain A. Indian J Chem., 2010, 49B, 351-355.

22. Holla B S, Mahalinga M, Poojary B, Ashok M and Akberali P M, Indian J Chem., 2006, 45B 568-571.

23. Jayashankara B and Rai K M L, J Chem., 2008, 5(2), 309-315;

DOI:10.1155/2008/570569

24. Maleki B, Azaarifar D, Moghaddam M K V, Hojati S F, Gholizadeh M and Salehabadi H, J Sebr Chem Soc., 2009, 74(12), 1371-1376.

25. Levai A, Kover K E and Jeko J, ARKIVOK, 2007, 8, 26-39.

26. Loh W, Quah C K, Chia T S, Fun H, Sapnakumri M, Narayana B and Sarojini B K, Molecules, 2013, 18(2), 2386-2396; DOI:10.3390/molecules18022386 
27. Shandala M Y and Hamdy A M, National J Chem., 2008, 30, 338-342.

28. Mokle S S, Vibhute A Y, Khansole S V, Zangade S B and Vibhute Y B, Res J Pharm Biol Chem Sci., 2010, 1(3), 631-638.

29. Suman K, Kumari R, Atulya M, Mathew M J and Ethiraj K R, Pharmaclogyonline, 2011, 2, 1411-1416.

30. Levai A and Jeko J, ARKIVOK, 2009, 6, 63-70.

31. Hawaiz F E, Omer S and Ahmed M S, Kirkuk University J Scientific Studies, 2012, 7(1), 50-66.

32. Revanasiddappa B C, Rao R N, Subrahmanyam E V S and Satyanarayana D, $J$ Chem., 2010, 7(1), 295-298; DO:10.1155/2010/415723

33. Shah S N N, Ziauddin H M, Zameer M, Khan T and Baseer M A, Int J Curr Pharm Res., 2011, 3(2),34-36.

34. Hareesh M, Mahanti S, Sailu B, Subramanyam D, Sakam S R, Tara B, Balram B, Vasudha B and Ram B, Der Pharma Chemica, 2012, 4(4), 1637-1643.

35. Joshi V D, Kshirsagar M D and Singhal S, Int J Chem Tech Res., 2012, 4(3), 971-975.

36. Azarifar D and Shaebanzadeh M. Molecules, 2002, 7, 885-895.

37. Ramesh B and Sumana T, J Chem., 2010, 7(2), 514-516; DOI:10.1155/2010/731675

38. Jyothi M V, Dinda S C, Reddy J R and Venkatesh P, J Chem Pharm Res., 2012, 4(5), 2626-2630.

39. Shinde S, Jadhav W, Pawar R and Bhusare S, J Chin Chem Soc., 2004, 51(4), 775-778; DOI:10.1002/jccs.200400117

40. Karabasanagouda T, Adhikari A V and Girisha M. Indian J Chem., 2009, 48B, 430-437.

41. Gothwal P and Srivastava Y K, J Chem Bio Phy Sci., 2012, 2(2), 622-627.

42. Adhikari A, Kalluraya B, Sujith K V, Gouthamchandra K, Jairam R, Mahmood R and Sankolli R, Eur J Med Chem., 2012, 55, 467-474; DOI:10.1016/j.ejmech.2012.07.002

43. Shah S N N, Ziauddin H M and Baseer M A, Pelagia Research Library, 2011, 2(5), 69-73. 